\title{
Redaction Criticism as a Resource for the Bible as "A Site of Struggle”
}

\author{
GERALD WEST (UKZN)
}

\begin{abstract}
Though the state, the church, theology, and biblical interpretation have been considered "sites of struggle" by South Africa's liberation theologies, the Bible has not. This article reappraises the work of South African Black theologian Itumeleng Mosala (thirty years later) and considers his particular understanding of the Bible as a site of struggle, drawing as he does on redaction criticism. The article analyses Mosala's notion of the ideological dimensions of redaction criticism, clarifies some of the concepts Mosala uses, argues for the role of literary methods in redactional criticism, and advocates for the inclusion of the "exploited classes" in the exegesis as well as the appropriation of biblical texts. Examples from Isaiah are used by way of explication.
\end{abstract}

KEYWORDS: African Biblical Hermeneutics, site of struggle, redaction criticism, Amos, Isaiah

\section{A INTRODUCTION}

South African Contextual Theology, a form of liberation theology with formative links to the worker movements of 1940s Europe, Latin American liberation theology, and the other theologies of resistance that emerged in response to the "low intensity conflict" political regimes common to Brazil, the Philippines, and South Africa in the mid-1980s, ${ }^{1}$ used the notion of "site of struggle” extensively.

For Contextual Theology, "The struggle is the opposite of the system."” The struggle for liberation from the system of apartheid (and its precursor

* Article submitted: 5/10/2016; peer-reviewed: 17/11/2016; accepted: 8/05/2017. Gerald West, "Redaction Criticism as a Resource for the Bible as 'A Site of Struggle'," Old Testament Essays 30 (2) 2017: 525-545, doi: http://dx.doi.org/10.17159/2312 -3621/2017/v30n2a19

1 For a series of essays on "Contextual Theology" see McGlory T. Speckman and Larry T. Kaufmann, eds., Towards an Agenda for Contextual Theology: Essays in Honour of Albert Nolan (Pietermaritzburg: Cluster Publications, 2001). For an inter-contextual collaborative theological engagement with these realities see ICT, The Road to Damascus: Kairos and Conversion (Johannesburg: Skotaville, 1989).

2 Albert Nolan, God in South Africa: The Challenge of the Gospel (Cape Town: David Philip, 1988), 157. 
settler-colonial systems) ${ }^{3}$ required the identification of particular "sites of struggle." Among the sites of struggle that were identified as sites of Christian engagement were the state as a site of struggle, the church as a site of struggle, and theology as a site of struggle. The South African Kairos Document (1985), one of the clearest articulations of Contextual Theology, declared that "Christians, if they are not doing so already, must quite simply participate in the struggle for liberation and a just society." 4 In the very next paragraph The Kairos Document goes on to analyse the church as a site of struggle, though it does not for strategic reasons use this terminology. ${ }^{5}$

The Kairos Document went further, boldly identifying Christian theology itself as a site of struggle. Indeed, the most significant contribution of The Kairos Document, as the product of an even more important process, was analysing South African theology as a site of struggle. What the struggle for liberation demonstrated, The Kairos Document argued, was that "theology" was itself contested. There was no single "Theology." The Kairos Document identified and analysed three contending theologies in the South Africa of the 1980s: State Theology, Church Theology, and Prophetic Theology. Briefly, "State Theology" was identified as the theology of the South African apartheid State which

is simply the theological justification of the status quo with its racism, capitalism and totalitarianism. It blesses injustice, canonises the will of the powerful and reduces the poor to passivity, obedience and apathy. 6

“Church Theology,” it was argued, was

[i]n a limited, guarded and cautious way ... critical of apartheid. Its criticism, however, is superficial and counter-productive because instead of engaging in an in-depth analysis of the signs of our times, it relies upon a few stock ideas derived from Christian tradition and then uncritically and repeatedly applies them to our situation. ${ }^{7}$

The Kairos Document deconstructs these two forms of theology and advocates for a "Prophetic Theology," a theology "that is biblical, spiritual, pastoral and, above all, prophetic" and that "speaks to the particular circumstances of this crisis, a response that does not give the impression of

3 Nolan, God in South Africa, 161.

4 Kairos, Challenge to the Church: The Kairos Document: A Theological Comment on the Political Crisis in South Africa (Braamfontein: The Kairos theologians, 1985), 22 §5.2. For a full set of "kairos” documents, see Gary S. D. Leonard, (Compiler), "The Kairos Documents,” Ujamaa Centre for Biblical and Theological Community Development and Research, University of Kwazulu-Natal, Online: http://ujamaa.ukzn .ac.za/Libraries/manuals/The_Kairos_Documents.sflb.ashx.

5 Kairos, The Kairos Document, 22 §5.1, 23 §5.3.

6 Kairos, The Kairos Document, $3 \S 2$.

7 Kairos, The Kairos Document, $8 \S 3$. 
sitting on the fence but is clearly and unambiguously taking a stand” against the apartheid system. ${ }^{8}$

However, while the state, the church, and theology were each recognised and analysed as intrinsically and inherently contested, the Bible was left untroubled as a site of struggle. Biblical interpretation was a site of struggle, ${ }^{9}$ but not the Bible itself. ${ }^{10}$ Indeed, The Kairos Document insisted that neither State Theology nor Church Theology has a "biblical foundation,"11 but that about Prophetic Theology, the Bible "has a great deal to say."12 The Kairos Document concludes with an "invitation” to

all committed Christians to take this matter further, to do more research, to develop the themes we have presented here or to criticise them and to return to the Bible, as we have tried to do, with the question raised by the crisis of our times. ${ }^{13}$

Stated even more clearly and strongly, the Revised Second Edition (1986) of The Kairos Document asserts that,

To be truly prophetic, our response would have to be, in the first place, solidly grounded in the Bible. Our KAIROS impels us to return to the Bible and to search the Word of God for a message that is relevant to what we are experiencing in South Africa today. ${ }^{14}$

But there was another theological trajectory, alongside South African Contextual Theology in the 1980s, and this is the trajectory of South African Black Theology. Representing the second phase of South African Black Theology, ${ }^{15}$ Itumeleng Mosala states clearly that, "the texts of the Bible are sites of struggle." 16 Though Mosala acknowledges that the final literary form of the biblical texts bear witness to these struggles, ${ }^{17}$ his primary focus is the sites of struggle that produced and are evident within the various redactional editions of the biblical text.

Here then are the two elements that this article brings into dialogue:

\footnotetext{
8 Kairos, The Kairos Document, 15 §4.

9 Kairos, The Kairos Document, 1, 4 §2.1.

10 Gerald O. West, "Tracing the 'Kairos' Trajectory from South Africa (1985) to Palestine (2009): Discerning Continuities and Differences,” JTSA 143 (2012):4-22.

11 Kairos, The Kairos Document, 14 §3.4.

12 Kairos, The Kairos Document, 16 §4.2.

13 Kairos, The Kairos Document, 24.

14 Kairos, The Kairos Document, 17 §4.1.

15 See Gerald O. West, The Stolen Bible: From Tool of Imperialism to African Icon (Leiden: Brill / Pietermaritzburg: Cluster Publications, 2016), 326-48.

16 Itumeleng J. Mosala, Biblical Hermeneutics and Black Theology in South Africa (Grand Rapids: Eerdmans, 1989), 185.

17 Mosala, Biblical Hermeneutics and Black Theology, 40.
} 
redactional editions as sites of struggle. I will begin by analysing aspects of redactional criticism, and then I will analyse how South African Black Theology uses the concept of the biblical text as "a site of struggle."

\section{B THE CONTOURS OF REDACTION CRITICISM}

Though there are a range of understandings of "redaction criticism," 18 Thomas Römer's recent explanation provides a useful entry point, which he sums up as follows: "'redaction' means the whole process of the literary formation of a text from its first written form to the last revisions that brought it into its definite shape." 19 Römer uses this notion of redaction because of its inclusive breadth, offering a place for rabbinic conceptions of successive rewriting, as when Baba Bathra 14a-15b of the Babylonian Talmud argues "that up to this point Moses wrote, from this point Joshua wrote" to account for the last eight verses of the Pentateuch. ${ }^{20}$ Within his conceptualisation Römer also includes the "reworking" of other ANE texts, such as the Gilgamesh epic. ${ }^{21}$ He differs, however, with John van Seters, who prefers the notion of author to that of redactor, precisely because in his view, most, if not all books of the HB are "composite."22

Though I would want to allow for a recognition of redactors who are more than editors, the advantage of the notion of redaction is that while it recognises affinities with literary notions of authorship, it remains focused on the composite nature of the process of literary formation. Biblical texts are the product of processes of collection and (re)composition. Indeed, it might be argued that the sacredness of biblical texts resides in the impulse to collect what has been of sacral significance to a particular social sector, but also to combine, via (re)composition, what has been collected into another "recomposition." For my analysis of the ideological dimensions of biblical texts it is important to acknowledge, as Robert Kugler does, that

the compilers who created what we often deem to be the most elegant texts - they are at their best when they have so obscured their sources and adapted genres that one sees only them and their meaning. And at that moment we are most fond to call them authors, missing mostly, or even altogether, that they were, like their lesser literary colleagues, redactors first. ${ }^{23}$

18 Thomas Römer, "Redaction Criticism: Hebrew Bible," in The Oxford Encyclopedia of Biblical Interpretation, ed. Steven L. McKenzie (Oxford: Oxford University Press, 2013).

19 Römer, "Redaction Criticism,” 224.

20 Römer, "Redaction Criticism,” 224.

21 Römer, “Redaction Criticism,” 228.

22 Römer, "Redaction Criticism,” 229.

23 Robert Kugler, "Redaction Criticism: Apocrypha and Deuterocanonical Books," in The Oxford Encyclopedia of Biblical Interpretation, ed. Steven L. McKenzie (Oxford: Oxford University Press, 2013), 239. 
The programmatic redactional work of Robert Coote on Amos draws on both the notion of textual "recompositions" and the notion of ideological contestation or struggle as a feature of such recompositions. ${ }^{24} \mathrm{I}$ invoke Coote here for two reasons. First, because he argues that his attention to "the process of production" of Amos "is just an example." He goes on immediately to state that, "To understand the process by which the book of Amos came into being is to learn an approach that will be useful with all prophetic literature.”25 I would go further and extend Coote's claim to most, if not all, biblical literature. As Kugler argues on the basis of his analysis of redactional work on the Apocryphal and Deuterocanonical books, "composing texts in antiquity was invariably a redactional activity in itself.” ${ }^{26}$ Second, I invoke Coote because Mosala builds on Coote's work in his ideological appropriation of the notion of redaction, and part of the purpose of this article is to reactivate, by way of a reappraisal (thirty years later), ${ }^{27}$ the ideological-redactional work of Mosala.

For Mosala the importance of Coote's redactional approach is that it acknowledges "what has thus far [1980s] been an elusive trait of scriptural texts: their class and ideological nature."28 However, while he applauds Coote's careful work on "the class nature and commitments of the various editions or recompositions of the prophetic texts," Coote "falls short," argues Mosala, "of providing an adequate hermeneutical appropriation of these texts in class and ideological terms." ${ }^{29}$ What Mosala is looking for is a recognition of "the question of 'struggle' as a fundamental hermeneutical factor in the text, as indeed in the communities behind the text and those appropriating the text presently."30

Mosala is quick to reject a redactional approach that recognises and valorises “an original prophet surrounded by secondary additions.”31 For Mosala, each redactional edition has its value, for it represents the contestation within a particular moment of socio-historical struggle. So redactional recognition "has as its purpose not the selection of one edition and the dismissal of others. On the contrary, the aim is to resurrect and identify the forces of struggle inherent and dominant in each edition."32 "Put simply," he says, ideological redactional

24 Robert B. Coote, Amos among the Prophets: Composition and Theology (Eugene: Wipf \& Stock, 1981), 2.

25 Coote, Amos among the Prophets, 2; Mosala, Biblical Hermeneutics and Black Theology, 124.

26 Kugler, “Redaction Criticism,” 239.

27 Itumeleng J. Mosala, "Biblical Hermeneutics and Black Theology in South Africa," (PhD diss., University of Cape Town, 1987).

28 Mosala, Biblical Hermeneutics and Black Theology, 125.

29 Mosala, Biblical Hermeneutics and Black Theology, 125.

30 Mosala, Biblical Hermeneutics and Black Theology, 125.

31 Mosala, Biblical Hermeneutics and Black Theology, 125.

32 Mosala, Biblical Hermeneutics and Black Theology, 125-26. 
analysis "acknowledges the value of all the editions of the texts." 33 But, he insists with respect to contemporary appropriation,

such value is variable: it could be positive or negative. It is fundamentally framed by the nature of the social and ideological struggles in the text as well as of similar struggles in the life of the readers. ${ }^{34}$

And while Mosala accepts the final form as a starting point for ideological redaction critical work, he recognises that the final form "cannot provide inspiration to oppressed peoples because it is inherently a theology of domination and control." 35 So, for Mosala, ideological redaction work is a necessity if we are to appropriate the Bible responsibly. A significant contribution of biblical studies to contemporary appropriations of biblical texts, Mosala maintains, is that it has "always been aware of the tendency in biblical literature for older traditions to be reused to address the needs of new situations." 36 What Mosala wants to add to this understanding is the ideological nature of the such reuse.

Before we analyse Mosala's analysis of the ideological reuse of older (and other) traditions, it is worth noting that Mosala's quest for a hermeneutic of appropriation of the resources of redaction criticism not only has heuristic potential for identifying the ideological identities of various redactional voices, it also, because of its liberation agenda, pushes redaction criticism towards the recognition of an oral, non-textual, source or even "edition." Mosala is not explicate about this, but I think he would have been persuaded on this point, for if the exploited classes are to have any place in the biblical text as a site of struggle we must posit their oral "textual" presence.

Römer, in his discussion of redaction, is careful to emphasise that "the term applies to all stages during which an original written text receives the forms that are reflected in the different manuscripts available to us," seeking to identify, "on the basis of a supposed original narrative, legal, poetic, or wisdom text, the different redactions that edited the text in the several stages of its development." ${ }^{37}$ For Römer, as with many biblical scholars, the "sources" used by redaction criticism are, in the words of David Carr, the "probable written sources embedded within” a text. ${ }^{38}$

33 Mosala, Biblical Hermeneutics and Black Theology, 126.

34 Mosala, Biblical Hermeneutics and Black Theology, 126.

35 Mosala, Biblical Hermeneutics and Black Theology, 134.

36 Mosala, Biblical Hermeneutics and Black Theology, 101.

37 Römer, "Redaction Criticism," 229. My emphasis.

38 David M. Carr, "Source Criticism," in The Oxford Encyclopedia of Biblical Interpretation, ed. Steven L. McKenzie (Oxford: Oxford University Press, 2013), 318. My emphasis. 
But if we cross the testamental boundary into redactional critical work on the gospels, there we find a form of redaction criticism (and source criticism) that recognises the use of "clusters of [source] material that may have been oral, literary, or some combination of both," the most well know of which is the so-called "Q" material, common to both Matthew and Luke, though not in Mark. ${ }^{39}$ So if we are to give what Norman Gottwald calls "the exploited classes" of the ancient world a voice in biblical texts, ${ }^{40}$ and if we are to recognise that "class" struggle inhabits biblical texts, including the contending voices of the exploited classes, as Mosala argues, we are probably referring to oral/aural "text," collected, composed, and performed in ways that scholars of Q have conjectured. ${ }^{41}$

\section{IDENTIFYING REDACTED AND REDACTIONAL VOICES}

Key to Mosala's understanding of the redactional task is the recognition that the voice of the prophet, in his case the prophet Micah, - even a prophet who stands and speaks, primarily, over against local city-temple states and, secondly, over against the imperial powers that struggle to exert their control over such local "Israelite" or "Judahite" city-temple states ${ }^{42}$ - even such a prophet always only "re-presents" the voice of the exploited classes. The voices of the exploited classes are always redacted, Mosala would argue, except in their fragmentary re-presentation and in the reverberations of their struggles on more dominant discourses.

These then are the two ends of an ideological orientation to redactional criticism. At the one end are the voices of the exploited classes; at the other end is the final form of the text. In-between are layers of redaction. However, as we have seen, Mosala is not denying that there are traces of even the most marginalised voices in the final literary layer. My own perspective, drawing on thinner notions of hegemony than Mosala's as well as poststructuralist notions of presence/absence, is that marginalised voices are always present in some form. ${ }^{43}$

39 C. Clifton Black, "Redaction Criticism: New Testament," in The Oxford Encyclopedia of Biblical Interpretation, ed. Steven L. McKenzie (Oxford: Oxford University Press, 2013), 240. I have deliberately brought the various articles on "redaction criticism" in this recent encyclopedia on biblical interpretation into critical dialogue.

40 Norman K. Gottwald, "A Hypothesis About Social Class in Monarchic Israel in the Light of Contemporary Studies of Social Class and Social Stratification," in The Hebrew Bible in Its Social World and in Ours, ed. Norman K. Gottwald (Atlanta: Scholars Press, 1993), 160. See also Roland Boer's discussion of the notion of “class" with respect to the ancient world and it "sacred economy"; Roland Boer, "The Sacred Economy of Ancient 'Israel,'” SJOT 21 (2007): 29-48.

41 Richard A. Horsley, ed. Oral Performance, Popular Tradition, and Hidden Transcript in $Q$, SemeiaSt 60 (Atlanta: Society of Biblical Literature, 2006).

42 Mosala, Biblical Hermeneutics and Black Theology, 148-49.

43 Gerald O. West, "The Not So Silent Citizen: Hearing Embodied Theology in the Context of HIV and AIDS in South Africa," in Heterotopic Citizen: New Research on 
The purpose of an ideologically determined (in both senses of the English word) redaction criticism is precisely to delve for each and every voice, no matter how "redacted."

The substantive contribution of Mosala with respect to redaction criticism is his elaboration of Coote's recognition of the ideological dimension of redactional recomposition. Mosala's own work on Micah follows the contours of Coote's work on Amos. However, it is important to note that Coote's work is focused on "the process by which the book of Amos came to be"; ${ }^{44}$ so, "in order to simplify," but "without distorting the evidence," he limits his analysis to "a three-stage process" of redaction. ${ }^{45}$ What this enables Coote to do with Amos is to identify three significant redactional editions, the oracles of the prophet Amos (stage A), ${ }^{46}$ a scribal recomposition of the oral oracles as they were "reactualized in the seventh century" (stage B), ${ }^{47}$ and an "updated" edition of "[a] resourceful, imaginative scribe who picked up and read the B stage of Amos sometime in the last third of the sixth century BC” (stage C). ${ }^{48}$

Mosala adopts Coote's three-stage process of his redactional analysis of Micah, ${ }^{49}$ though he does not argue as Coote does that a three-stage process is line with the redactional scholarship on Micah. Coote is aware, with respect to Amos, that redactional scholarship has made an argument for more than one stage B edition, between the original oracles and the final form. He is clear that "to reduce the composition of the book of Amos to a three-stage process is an oversimplification,"50 and only does so in order to illustrate the redactional process. He recognises that "the analysis of stages of composition has to be done separately for each prophetic book." 51 Coote is overt about his oversimplification; Mosala is not.

What the oversimplification does is allow Coote to demonstrate a redactional process, how the "Bethel editor" (stage $\mathrm{B}$ ) collected some of the oracles of Amos (stage A), combining them together in a written recomposition with his own compositions, and how the stage $C$ editor "rewrote this work with the addition of an opening and closing." 52 Coote describes this three-stage process carefully, acknowledging throughout that the redactional detail could be

Religious Work for the Disadvantaged, ed. Trygve Wyller (Göttingen: Vandenhoeck \& Ruprecht, 2009).

44 Coote, Amos among the Prophets, 2.

45 Coote, Amos among the Prophets, 3.

46 Coote, Amos among the Prophets, 11-45.

47 Coote, Amos among the Prophets, 47, 46-109.

48 Coote, Amos among the Prophets, 110-11, 10-34.

49 Mosala, Biblical Hermeneutics and Black Theology, 126.

50 Coote, Amos among the Prophets, 8.

51 Coote, Amos among the Prophets, 9.

52 Coote, Amos among the Prophets, 5. 
elaborated. What Coote wants us to understand is that recomposition "involves selection, retelling, organizing." 53 And though Coote is not as explicit about the ideological dimensions of recomposition as Mosala, his analysis of the redactional process is implicitly ideological.

Mosala's emphasis is not so much the redactional process as the identification of the ideological voices within each redaction. Mosala works backwards towards the prophet, tracing the various redactional voices from the final form back in history and sociological setting towards the voice of the prophet (and the exploited classes represented by the prophet). Working backwards in Mosala-like fashion from the final redactional form we may posit the most prevalent voice in this edition as the voice of the dominant ideology, with hegemonic aspirations, for "[t]he perspective of these texts frames the various other layers of meaning of the discourse in such a way as to relegate these layers of meaning to a secondary position."54 Mosala is here drawing on and attempting to integrate Stuart Hall' ${ }^{55}$ work on ideological coding with the sociological analysis of scholars in the trajectory of Norman Gottwald, ${ }^{56}$ Marvin Chaney, ${ }^{57}$ and Roland Boer. ${ }^{58}$ This final redaction or "signifying practice," Coote's stage C, derives from "ruling class groups," including Israelite and Judahite royal houses, temple-city aligned priests, and temple-city-based land-owners and merchants.

This form of the prophetic text takes up, partially co-opting - for hegemonic appropriations are never complete in their attempts to re-codify the voices they subsume ${ }^{59}$ - the professional or scribal, economically "middle layer," 60 stage B (in Coote's terms) re-presentations of the prophet's oral or written text, depending on the prophet. This scribal voice tends to accommodate its re-presentation to the ruling class it serves and subsists on, ${ }^{61}$ using a form of

\footnotetext{
53 Coote, Amos among the Prophets, 4.

54 Mosala, Biblical Hermeneutics and Black Theology, 131.

55 Mosala, Biblical Hermeneutics and Black Theology, 41-42.

56 Gottwald, "Hypothesis"; Norman K. Gottwald, "Sociological Method in the Study of Ancient Israel," in The Bible and Liberation: Political and Social Hermeneutics, ed. Norman K. Gottwald and Richard A. Horsley (Maryknoll: Orbis, 1993).

57 Marvin L. Chaney, "Bitter Bounty: The Dynamics of Political Economy Critiqued by the Eighth-Century Prophets," in The Bible and Liberation: Political and Social Hermeneutics, ed. Norman K Gottwald and Richard A Horsley (Maryknoll: Orbis, 1993); Marvin L. Chaney, "Micah - Models Matter: Political Economy and Micah 6:9-15," in Ancient Israel: The Old Testament in Its Social Context, ed. Philip F. Esler (Minneapolis: Fortress Press, 2006).

58 Boer, "Sacred Economy"

59 James C. Scott, Domination and the Arts of Resistance: Hidden Transcripts (London: Yale University Press, 1990).

60 Mosala, Biblical Hermeneutics and Black Theology, 117.

61 Mosala, Biblical Hermeneutics and Black Theology, 141.
} 
what Hall calls "negotiated code,"62 but with an emphasis on the "adaptive" rather than the "oppositional" elements of this code. ${ }^{63}$ This redactional voice, Mosala argues, tends to be "shot through with contradictions," arising from, in Hall's words, "the differential position of those who occupy this position in the spectrum, and from their differential and unequal relation to power." ${ }^{\prime 4}$

The voice redacted by the scribal voice is that of the prophet, though Coote admits that "it is doubtful that the first recorder of Amos's words in writing was Amos himself." ${ }^{65}$ Like so many OT/HB redactional scholars, Coote cannot imagine an oral-aural "composition." As envisaged by both Coote and Mosala, the prophet is a socially engaged intellectual, either organic to or in solidarity with the exploited classes, those excluded from the discourses of the city-temple state and the encompassing systems of empire, re-presenting them as he (or she) speaks to the dominant power structures. Here too we can posit the use of a form of negotiated code, ${ }^{66}$ except here the use of oppositional elements is more pronounced. Yet even here adaptive elements are included in order to have the oppositional elements heard in the struggle with ruling class power. Among the exploited classes, if we follow the astute ideological analysis of James Scott, would be both a public and a hidden "transcript," ${ }^{17}$ with the hidden transcript reserved for talk among themselves and the public transcript being shared with the prophetic sectors in solidarity with them. The prophet would then "re-member" 68 the public components, reconfiguring them in a strategic and substantive form within his oral-aural performances - strategically to secure access to state power and substantially to talk-back to state power.

Which then brings us to the voices of the exploited classes themselves, for as Mosala reiterates, "[t]he task of a biblical hermeneutics of liberation is to go behind the dominant discourses to the discourses of oppressed communities in order to link up with kindred struggles." ${ }^{\text {69 }}$ However, somewhat strangely neither Coote nor Mosala postulate a distinctive "textual" layer for the exploited classes. They are always only re-presented. But if we use redactional notions from gospel research we can posit an oral "textual" layer, whose public transcript the prophet has access to. ${ }^{70}$ As Scott so carefully argues, ${ }^{71}$ the exploited classes are not silent,

\footnotetext{
62 Mosala, Biblical Hermeneutics and Black Theology, 42, 138.

63 Mosala, Biblical Hermeneutics and Black Theology, 141.

64 Mosala, Biblical Hermeneutics and Black Theology, 138.

65 Coote, Amos among the Prophets, 7.

66 Mosala does not make this distinction, for he does not separate out the prophet clearly from the sectors the prophet represents.

67 Scott, Domination and the Arts of Resistance.

68 West, The Stolen Bible, 363-65.

69 Mosala, Biblical Hermeneutics and Black Theology, 153.

70 Though Mosala does analyse Luke 1-2, he does not delve into gospel redaction criticism; see Mosala, Biblical Hermeneutics and Black Theology, 154-72. Indeed, in his work on Luke Mosala takes up more of a literary approach than a redactional
} 
for they "create and defend a social space in which offstage dissent to the official transcript of power relations may be voiced." 72 And when they do venture to speak in the public realm, their speech takes on "a dialogic form in which the language of the dialogue will invariably borrow heavily from the terms of the dominant ideology prevailing in the public transcript." ${ }^{\text {"73 }}$ The dominant discourse becomes, then, "a plastic idiom or dialect that is capable of carrying an enormous variety of meanings, including those that are subversive of their use as intended by the dominant," for in most contexts of domination "the terrain of dominant discourse is the only plausible arena of struggle."74 So by recognising that adopting and adapting the dominant discourse is a guise induced by power relations that is necessary outside of the safety of the hidden transcript, and by learning to read the dialects and codes generated by the techniques and arts of resistance, we can discern a dialogue with power in the public transcript. ${ }^{75}$

The voices of the exploited classes are a real presence, even in redaction. Ideological analysis along the lines of Scott's is required to enable us to recognise this real presence. And, as I will argue in the next section, given this recognition, we then need appropriate tools with which to identify the textual presence of these voices.

In this section I have begun to re-envision Mosala's analysis of ideological-redactional voices. What I have taken from Mosala is his insistence that there are distinguishable voices and that they are engaged in a "class" struggle across a biblical text's redactional history. What makes recognising and recovering these contending voices so difficult is the reality of redactional work, namely, that it is not additive, with one voice being added on top of another voice. As Coote argued with respect to Amos, redactional work is about re-vision and re-writing rather than addition or accretion. ${ }^{76}$ Redaction is a

approach; Mosala, Biblical Hermeneutics and Black Theology, 161. Like so many scholars, Mosala is hampered by the scholarly traditions of Old Testament scholarship. In honouring I. J. J. "Sakkie” Spangenberg, I acknowledge a scholar who traverses not only the boundary between the academy and the community, but also the boundary between the testaments.

71 For a fuller discussion see Gerald O. West, "Explicating Domination and Resistance: A Dialogue between James C. Scott and Biblical Scholars,” in Hidden Transcripts and the Arts of Resistance: Applying the Work of James C. Scott to Jesus and Paul, ed. Richard A. Horsley, SemeiaSt (Atlanta: Society of Biblical Literature / Leiden: E. J. Brill, 2004); Gerald O. West, "Newsprint Theology: Bible in the Context of HIV and AIDS," in Out of Place: Doing Theology on the Crosscultural Brink, ed. Jione Havea and Clive Pearson (London: Equinox Publishing, 2011).

72 Scott, Domination and the Arts of Resistance, xi.

73 Scott, Domination and the Arts of Resistance, 102.

74 Scott, Domination and the Arts of Resistance, 102-03.

75 Scott, Domination and the Arts of Resistance, 101-05, 38.

76 Coote, Amos among the Prophets, 5. 
process of "gradual combination and recomposition."77

\section{ADDITIONAL REDACTIONAL TOOLS}

This recognition of the nature of redactional activity is important. The entangled nature, across time, ${ }^{78}$ of various voices, engaged in conversation and even contestation, requires careful tools of discernment. And while the traditional set of historical-critical tools associated with redaction criticism offer significant resources, other tools too are required.

As I indicated earlier, one of reasons I think that redactional criticism has so much potential for ideological "voice" recognition and appropriation is that it so closely approximates literary forms of analysis. Mosala seems to acknowledge this when he admits that "black theologians are correct in detecting glimpses of liberation and of a determinate social movement galvanised by a powerful religious ideology in the biblical text." ${ }^{\text {"9 }}$ The problem for Mosala is not "[t]he existence of this phenomenon," but "of developing an adequate hermeneutical framework that can rescue those liberating themes from the biblical text." 80 For this Mosala turns to redaction criticism, within an ideologically-driven form of sociological criticism.

But literary tools have come a long way since the 1980s, when Mosala was doing his work. Mosala is justifiably worried by interpretations that follow the ideological grain of the text, ${ }^{81}$ what the literary biblical scholar Denis Olson refers to as the "constructive literary approaches" characteristic of the 1970s and 1980s, in which "scholars often assumed a basic unity, structure, and coherence in the text." ${ }^{\prime 22}$ However, with the recognition of the presence of real readers and their role "in constructing meaning from texts,"

literary scholars began to question the new critic's assumption about the stability of literary texts with a unified meaning. They also resisted structuralism's assumption of a set of universal binary oppositions that transcend cultural and social location. ${ }^{83}$

Alongside this reader-centred generated recognition, text-centred approaches themselves became more focused “'in' the details of the text itself," recognising both the text's "internal complexity" and the text's "gaps and

77 Coote, Amos among the Prophets, 3.

78 I am here invoking Achille Mbembe's notion of "entangled time"; Achille Mbembe, On the Postcolony (Berkeley: University of California Press, 2001), 16.

79 Mosala, Biblical Hermeneutics and Black Theology, 40. My emphasis.

80 Mosala, Biblical Hermeneutics and Black Theology, 40.

81 Mosala, Biblical Hermeneutics and Black Theology, 32, 41, 123-53, 73-89.

82 Dennis T. Olson, "Literary and Rhetorical Criticism," in Methods for Exodus, ed. Thomas B. Dozeman (Cambridge: Cambridge University Press, 2010), 16.

83 Olson, "Literary and Rhetorical Criticism," 19. 
omissions." 84 The grain of the text was destabilised from without by the reader and from within by the text's own detail and (poststructural) gaps, each of which are ideologically determined (in both senses of the English word). Such "deconstructive literary approaches" are better equipped to do the work Mosala envisages at the textual level. With them we are able to detect more detailed glimpses of the struggles that produced the text, in the text.

It needs to be clear at this point in my argument that by "text" I mean any recoverable redactional edition or source. Literary analysis tends to be linked with an analysis of the "final form" of the biblical text. But this is not a necessary linkage. Indeed, I would argue, literary forms of analysis have been somewhat stigmatised by their association with the final form of the biblical text. Literary tools can be used on any socio-historically recovered text, whether it be a redactional source text or a redactional edition. I envisage literary analysis, particularly its deconstructive dimensions, having two related areas of contribution within redactional critical work. First, while redactional analysis in biblical scholarship tends to remain within its own scholarly trajectory, with redactional scholars engaging with the work that redactional criticism has produced, this redaction-replicating cycle should be interrogated. Bracketing, for a moment the substantial redactional scholarly tradition, constructive and deconstructive literary analysis of the final form text may offer alternative avenues of redactional exploration. Second, and I think more strategically, for it is unrealistic to imagine redaction criticism abandoning its historical heritage, literary analysis could be used to identify and interpret the contending ideological voices within a particular redacted source text or redactional edition.

Two brief examples from the book of Isaiah will illustrate my argument. In his work on the ethics of biblical prophecy, David Pleins revisits the extensive redactional work done on Isaiah via a canonical approach. ${ }^{85}$ Though not a fully fledged literary analysis of the final canonical form of Isaiah, ${ }^{86}$ Pleins does use aspects of literary-ideological analysis, particularly "the competing [thematic as] theological trajectories of the text." ${ }^{87}$ A close and careful re-reading of the final canonical form, while redactional considerations hover in the background, enables Pleins to identify significant thematic and ideological trajectories. His approach, which combines literary and redactional analysis, enables him to identify contending notions of "the poor" ( 'anî / 'ănāwîm).

84 Olson, "Literary and Rhetorical Criticism," 19.

85 David J. Pleins, The Social Visions of the Hebrew Bible: A Theological Introduction (Louisville: Westminster John Knox Press, 2001), 223-25.

86 Pleins follows the canonical approach of Brevard Childs, which presupposes a historical-critical orientation, including a strong role for redactional criticism; see the discussion in Mark G. Brett, Biblical Criticism in Crisis? (Cambridge: Cambridge University Press, 1991).

87 Pleins, The Social Visions of the Hebrew Bible, 224. 
The early chapters of Isaiah [deriving from the prophet] depict the members of the urban establishment as exhausting the produce of the vineyard, God's people, and taking the property of the 'ani (3:13-14). The driving concern of the decadent upper classes is depicted as enhancing pleasure and increasing material prosperity ... (5:22-23; cf. $5: 18-21){ }^{88}$

Furthermore, continues Pleins,

the prophet specifies the mode of exploitation adopted by the rich: "Ah ['Woe to'] those who add house to house and join field to field, till there is room for none but you to dwell in the land" (5:8) ${ }^{89}$

In sum, argues Pleins, “[t]he prophetic critique is clear: The prosperity of the wealthy is directly linked to injustices against other members of Israelite society." ${ }^{\circ 0}$ Poverty and wealth are directly and systemically related; the poor are poor because the wealthy have exploited them. ${ }^{91}$

However, "the poor" are reframed in subsequent redactions as the voices of the poor and their prophet are redacted by elite-aligned scribal voices. Though this recomposition of "the poor" is evident in chs. 40-66, it is particularly prevalent in 55-66, argues Pleins, where the terms 'anî / 'ănāwim are used to "reconceptualize the experience of Israel's dislocated elite."92 However, Pleins argues, even ch. 1-39 have been recomposed in this regard. Referring to Isa 26:1-7 Pleins states:

Presumably here the "poor and needy" are the returning exiles who will lay claim to the seats of power. One does not imagine here a proletarian revolution of the Marxist variety. As will become clear in our discussion of chaps. 40-66, the exile has brought about an adaptation of the ancient prophetic call for justice for the poor. Where once this language may indeed have been spoken in relation to the concrete needs of Israel's oppressed, this language has, with the exile, been amalgamated, via prophetic recasting, into the political program of the displaced elite in ancient Israel. ${ }^{93}$

Materials in Isa 1-39 that may have their social location in ideological codes connected to the poor of Palestine "have been grossly recast to follow the theological project of the postexilic author(s)." "94 The voices of the poor have been coopted; the problem is no longer systemic economic oppression but sin in

88 Pleins, The Social Visions of the Hebrew Bible, 254.

89 Pleins, The Social Visions of the Hebrew Bible, 254.

90 Pleins, The Social Visions of the Hebrew Bible, 254.

91 Pleins, The Social Visions of the Hebrew Bible, 254-59.

92 Pleins, The Social Visions of the Hebrew Bible, 264.

93 Pleins, The Social Visions of the Hebrew Bible, 251.

94 Pleins, The Social Visions of the Hebrew Bible, 264. 
a more general moral sense $(50: 1 ; 59: 1-4) .{ }^{95}$ Referring directly to Mosala's work, Pleins concludes:

Such a shift would appear to mimic that identified by Mosala for Micah, wherein an original prophetic critique of social injustice is later toned down into a message about abstract "justice," only to finally be commandeered by the elite as a message about its own predicament of judgement. ${ }^{96}$

His attentiveness to the literary-thematic dimensions of the final canonical form, cognisant as he is of redactional-critical scholarship, enables Pleins to discern within the text how key concepts such as "the poor" shift across history and ideology.

My second example is from the work of Mark Brett, another biblical scholar with an ear and eye of the ideological dimensions of text. Brett too combines forms of literary analysis with detailed redactional-critical reconstruction. Brett focuses on Isa 56-66, demonstrating, by "addressing the literary complexity” of this redaction, "a significant continuity of imperial social imagination that imbues all of Isa 40-66," and arguing that "exegetes need to explore in greater depth the complex mix of mimicry and resistance within Third Isaiah."97

With other scholars, Brett recognises a "nationalist-universalist" vision that both a second redaction (Second Isaiah) and a third redaction (Third Isaiah) have written into the text, in which there will be a "universal rule," but a form of rule that "will mean salvation for Israel but submission for the other nations."98 As an example of this nationalist-universalist "justice," Brett identifies "a clear hierarchy" in Isa 61:5-6, "which sets the holy people who are given sacred labor (cf. 62:12) over those who are given profane labor" (61:5-6). ${ }^{99}$ "This

95 Pleins, The Social Visions of the Hebrew Bible, 265. As one of the reviewers of my article has pointed out, referring me to the work of Paul Hanson, the returned exiles were not homogenous, with some of the returned exiles marginalised by those exiles who were associated with the temple establishment; see Paul D. Hanson, The Dawn of Apocalyptic: The Historical and Sociological Roots of Jewish Apocalyptic Eschatology, rev. ed. (Philadelphia: Fortress Press, 1979), 240. Both Hanson and the reviewer make a cogent argument for a nuanced analysis of the presence of contending ideologies, even within a social sector. As my next example demonstrates, Mark Brett's work is attentive to such nuance. It is precisely the presence of nuanced and entangled ideological traces that requires discerning redactional methodological capacity.

96 Pleins, The Social Visions of the Hebrew Bible, 267.

97 Mark G. Brett, "Imperial Imagination in Isaiah 56-66," in Isaiah and Imperial Context: The Book of Isaiah in the Times of Empire, ed. Andrew T. Abernethy, et al. (Eugene: Wipf and Stock, 2013), 167.

98 Brett, "Imperial Imagination," 168; the second quotation is cited by Brett from R. N. Whybray, Isaiah 40-66 (London: Oliphants, 1975), 72.

99 Brett, “Imperial Imagination,” 168. 
stratification is somewhat deconstructed, however," Brett argues, "in the 'bookends' of 56:1-8 and 66:18-24, where even foreigners might enter the cultic service of YHWH." ${ }^{100}$ Brett recognises this deconstruction through his ideologically astute adjustments (in italics) to the chaistic structure John Goldingay identifies in Third Isaiah:

\section{6:1-8 Foreigners in sacred service}

56:9-59:8 YHWH's challenges concerning the Jerusalem community's life

59:9-15a Prayers for YHWH's forgiveness and restoration

59:15b-21 Vision of YHWH acting in judgment

60:1-61:4 Vision of Jerusalem restored

61:5-6 Foreigners in secular service

61:7-62:12 Vision of Jerusalem restored

63:1-6 Vision of YHWH acting in judgment

63:7-64:11 Prayers for YHWH's forgiveness and restoration

65:1-66:17 YHWH's challenges concerning the Jerusalem community's life 66:18-24 Foreigners in sacred service ${ }^{101}$

Contrary to the view that divine justice in Isa 40-66 is entirely ethnocentric and "will mean salvation for Israel but submission for the other nations," the combination of Isa 56:1-8 and 61:1-11 may imply,

Brett argues, "that divine justice can include both the redemption of families to their ancestral country and an invitation to the Gentiles to be part of this imperial order." ${ }^{102}$ What Brett's careful literary and redactional analysis enables us to recognise is that

instead of seeing prophetic and priestly groups pitted against each other in Isa 56-66, it is more plausible to see a range of prophetic and priestly groups each expressing in their own ways the sovereignty of YHWH over against the pretentions of Persian power.

However, Brett continues,

Ironically, the articulation of this resistance has actually mimicked imperial symbolism, a mimetic dynamic that is commonly found both in modern colonial history as well as in the ancient unfolding of biblical theology in the tides of successive empires. ${ }^{103}$

The recognition of the capacity of deconstructive literary resources to discern contending voices within biblical texts not only makes a potential contribution to redaction criticism, it also offers a place for collaboration with non-scholarly ${ }^{104}$ readers of the Bible. For the tools of biblical scholars are not

100 Brett, “Imperial Imagination,” 168.

101 Brett, "Imperial Imagination," 169.

102 Brett, "Imperial Imagination,” 178. Brett is here citing Whybray, Isaiah 40-66, 72.

103 Brett, “Imperial Imagination,” 180.

104 Teresa Okure, "Feminist Interpretation in Africa," in Searching the Scriptures: A 
sufficient. Working within the South African context during the struggle against apartheid, when white voices spoke for and on behalf of Black South Africans, consuming their labour and re-presenting their absent voices within the political realm, ${ }^{105}$ Mosala attempts both to disentangle Black voices from within apartheid discourse and to disentangle kindred oppressed voices from within the discourse of the final form of prophetic books. Indeed, for Mosala these two tasks are related, for, he argues, "unstructural understanding of the Bible may simply reinforce and confirm unstructural understanding of the present."106

Attentiveness to both textual and contextual structural or systemic analysis is vital precisely because the final form of the biblical text is ideologically inappropriate for the exploited classes of contemporary contexts. Indeed, Mosala argues that

contemporary struggles for liberation, having encountered a void in terms of the actual struggles of the poor and exploited in the text, must offer their struggles - hermeneutically speaking - to complete the text. ${ }^{107}$

In order to do this, they use, in Terry Eagleton's terms, one's “own signifying practices to enrich, modify or transform the effects which others' practices produce."108

Stated more fully, his argument with respect to the importance of contemporary struggles for liberation as an exegetical resource is that

there are enough contradictions within ... [biblical texts] to enable eyes that are hermeneutically trained in the struggle for liberation today to observe the kin struggles of the oppressed and exploited of the biblical communities in the very absences of those struggles in the text. ${ }^{109}$

The contradictions are embodied - textually inscribed - within the final

Feminist Introduction, ed. Elisabeth Schussler Fiorenza (New York: Crossroads, 1993), 77.

105 Sampie Terreblanche, A History of Inequality in South Africa, 1652-2002 (Pietermaritzburg: University of Natal Press, 2002).

106 Gottwald, cited in Mosala, Biblical Hermeneutics and Black Theology, 31-32. Norman K. Gottwald, "Socio-historical precision in the biblical grounding of liberation theologies,” Address to the Catholic Biblical Association of America at its annual meeting, San Francisco, August 1985.

107 Mosala, Biblical Hermeneutics and Black Theology, 149.

108 Cited in Mosala, Biblical Hermeneutics and Black Theology, 149. See also Mosala, Biblical Hermeneutics and Black Theology, 153.

109 Itumeleng J. Mosala, “The Use of the Bible in Black Theology,” in The Unquestionable Right to Be Free: Essays in Black Theology, ed. Itumeleng J. Mosala and Buti Thagale (Johannesburg: Skotaville, 1986), 196. 
form of the text because, insists Mosala, the Bible is itself "a product and a record of class struggles." ${ }^{110}$ Black theologians, because of their social location within the struggle against apartheid, were able, Mosala argues, to detect "glimpses of liberation and of a determinate social movement galvanized by a powerful [liberation] religious ideology in the biblical text." ${ }^{111}$ But because of the "middle-class origins and character" of South African Black Theology, ${ }^{112}$ even Black Theology required an interpretive alliance with the epistemological eyes of the most oppressed, whom Mosala refers to in class terms as "the 'commoners." "113 So the exploited classes may have an exegetical contribution to make, working alongside biblical scholars in recovering what has been redacted, and giving voice to a fuller presence to the poor and exploited classes in the text and to a more contextually appropriate appropriation of the redactional ideologies of the text.

Returning to Isaiah for the final time, we can imagine a reading process in which contemporary poor and exploited South African users of the Bible might do forms of "struggle-trained" exegesis with socially engaged biblical scholars. ${ }^{114}$ We could, for example, offer them access to those texts Pleins identifies as showing the shift in the identities of "the poor" and hear what additional resources they would bring to these texts and to the very idea that the identity of "the poor" shifts within different ideological discourses. We could also, for example, focus on Brett's contending chiastic voices in our work with the foreign poor in South Africa, ${ }^{115}$ inviting them to offer their understanding of the dynamics of this contestation.

So redactional critical work, if it is ideologically astute, on the final form of biblical books requires other classes besides the middle-class biblical scholar. Struggle-trained-eyes are necessary. But the tools they will take up with their ideologically attuned middle-class biblical scholar compatriots are the products of an ideologically attentive literary and redactional criticism.

\section{E REDACTING CLASS STRUGGLE}

Among the denotations of the verb "redact" is the notion of "censure" or "obscure." So it is somewhat ironic that I am arguing in this article that redaction

110 Mosala, "The Use of the Bible in Black Theology," 196.

111 Mosala, Biblical Hermeneutics and Black Theology, 40.

112 Mosala, Biblical Hermeneutics and Black Theology, 96.

113 Mosala, Biblical Hermeneutics and Black Theology, 97.

114 Gerald O. West, ed. Reading Other-Wise: Socially Engaged Biblical Scholars Reading with Their Local Communities, SemeiaSt 62 (Leiden: E. J. Brill / Atlanta: Society of Biblical Literature, 2007).

115 Gerald O. West and Sithembiso Zwane, “'Why Are You Sitting There?’ Reading Matthew 20:1-16 in the Context of Casual Workers in Pietermaritzburg, South Africa," in Matthew: Texts@Contexts, ed. Nicole Duran Wilkinson and James Grimshaw (Minneapolis: Fortress Press, 2013). 
criticism may be used to recover, include, and make known voices that have been censured and obscured. Yet Mosala's task remains relevant in the South Africa of today, more than two decades after political liberation, for we have come to embrace, as Mosala might have predicted, "a false notion of the Bible as nonideological," which "leaves the privilege of a political reading of the Bible to the hegemonic sectors of society," for they "do not have to strain after an explicitly political reading since the texts of the Bible are themselves already cast in hegemonic codes."116

To read against such hegemonic interpretations requires ideologically attuned (literary and) redactional resources, for "biblical texts do not become politically supportive of the black struggle just because they are being appropriated from its perspective.” The task is more complex, for "[t]o engage a biblical text in the light of the black struggle for liberation may be to take sides in and to connect with kindred struggles that were being waged in very ancient communities," 117 which is only possible if we are able to recognise the Bible as a site of struggle within which we attempt to access, via redactional criticism, ideologically co-opted voices in the midst of their own distinctive sectoral struggles.

\section{BIBLIOGRAPHY}

Black, C. Clifton. "Redaction Criticism: New Testament.” Pages 240-51 in The Oxford Encyclopedia of Biblical Interpretation. Edited by Steven L. McKenzie. Oxford: Oxford University Press, 2013.

Boer, Roland. “The Sacred Economy of Ancient 'Israel.” SJOT 21/1 (2007): 29-48.

Brett, Mark G. Biblical Criticism in Crisis? Cambridge: Cambridge University Press, 1991.

. “Imperial Imagination in Isaiah 56-66.” Pages 167-81 in Isaiah and Imperial Context: The Book of Isaiah in the Times of Empire. Edited by Andrew T.

Abernethy, Mark G. Brett, Tim Bulkeley and Tim Meadowcroft. Eugene: Wipf and Stock, 2013.

Carr, David M. “Source Criticism.” Pages 318-26 in The Oxford Encyclopedia of Biblical Interpretation. Edited by Steven L. McKenzie. Oxford: Oxford University Press, 2013.

Chaney, Marvin L. "Bitter Bounty: The Dynamics of Political Economy Critiqued by the Eighth-Century Prophets." Pages 250-63 in The Bible and Liberation:

Political and Social Hermeneutics. Edited by Norman K. Gottwald and Richard

A. Horsley. Maryknoll: Orbis, 1993.

“Micah - Models Matter: Political Economy and Micah 6:9-15.” Pages

145-60 in Ancient Israel: The Old Testament in Its Social Context. Edited by

Philip F. Esler. Minneapolis: Fortress Press, 2006.

Coote, Robert B. Amos among the Prophets: Composition and Theology. Eugene: Wipf \& Stock, 1981.

116 Mosala, Biblical Hermeneutics and Black Theology, 6. See West, Stolen Bible, 445-542.

117 Mosala, Biblical Hermeneutics and Black Theology, 8. 
Gottwald, Norman K. "A Hypothesis About Social Class in Monarchic Israel in the Light of Contemporary Studies of Social Class and Social Stratification.” Pages 139-64 in The Hebrew Bible in Its Social World and in Ours. Edited by Norman K. Gottwald. Atlanta: Scholars Press, 1993. . "Sociological Method in the Study of Ancient Israel." Pages 142-53 in The Bible and Liberation: Political and Social Hermeneutics. Edited by Norman K. Gottwald and Richard A. Horsley. Maryknoll: Orbis, 1993.

Hanson, Paul D. The Dawn of Apocalyptic: The Historical and Sociological of Jewish Apocalyptic Eschatology. Rev. ed. Philadelphia: Fortress Press, 1979.

Horsley, Richard A., ed. Oral Performance, Popular Tradition, and Hidden Transcript in Q. SemeiaSt 60. Atlanta: Society of Biblical Literature, 2006.

ICT. The Road to Damascus: Kairos and Conversion. Johannesburg: Skotaville, 1989.

Kairos. Challenge to the Church: The Kairos Document: A Theological Comment on the Political Crisis in South Africa. Braamfontein: The Kairos theologians, 1985.

Kugler, Robert. "Redaction Criticism: Apocrypha and Deuterocanonical Books.” Pages 232-40 in The Oxford Encyclopedia of Biblical Interpretation. Edited by Steven L. McKenzie. Oxford: Oxford University Press, 2013.

Leonard, Gary S. D. (Compiler). “The Kairos Documents.” Ujamaa Centre for Biblical and Theological Community Development and Research. University of

Kwazulu-Natal. Online: http://ujamaa.ukzn.ac.za/Libraries/manuals/The_Kairos _Documents.sflb.ashx.

Mbembe, Achille. On the Postcolony. Berkeley: University of California Press, 2001.

Mosala, Itumeleng J. Biblical Hermeneutics and Black Theology in South Africa. Grand Rapids: Eerdmans, 1989. . "Biblical Hermeneutics and Black Theology in South Africa." PhD diss., University of Cape Town, 1987. . "The Use of the Bible in Black Theology." Pages 175-99 in The Unquestionable Right to Be Free: Essays in Black Theology. Edited by Itumeleng J. Mosala and Buti Tlhagale. Johannesburg: Skotaville, 1986.

Nolan, Albert. God in South Africa: The Challenge of the Gospel. Cape Town: David Philip, 1988.

Okure, Teresa. "Feminist Interpretation in Africa.” Pages 76-85 in Searching the Scriptures: A Feminist Introduction. Edited by Elisabeth Schussler Fiorenza. New York: Crossroads, 1993.

Olson, Dennis T. "Literary and Rhetorical Criticism." Pages 13-54 in Methods for Exodus. Edited by Thomas B. Dozeman. Cambridge: Cambridge University Press, 2010.

Pleins, David J. The Social Visions of the Hebrew Bible: A Theological Introduction. Louisville: Westminster John Knox Press, 2001.

Römer, Thomas. "Redaction Criticism: Hebrew Bible.” Pages 223-32 in The Oxford Encyclopedia of Biblical Interpretation. Edited by Steven L. McKenzie. Oxford: Oxford University Press, 2013.

Scott, James C. Domination and the Arts of Resistance: Hidden Transcripts. London: Yale University Press, 1990.

Speckman, McGlory T. and Larry T. Kaufmann, eds. Towards an Agenda for Contextual Theology: Essays in Honour of Albert Nolan. Pietermaritzburg: Cluster Publications, 2001.

Terreblanche, Sampie. A History of Inequality in South Africa, 1652-2002. 
West, “Redaction Criticism as a Resource,” OTE 30/2 (2017): 525-545

Pietermaritzburg: University of Natal Press, 2002.

West, Gerald O. "Explicating Domination and Resistance: A Dialogue between James C. Scott and Biblical Scholars.” Pages 173-94 in Hidden Transcripts and the Arts of Resistance: Applying the Work of James C. Scott to Jesus and Paul. Edited by Richard A. Horsley. SemeiaSt. Atlanta: Society of Biblical Literature / Leiden: E. J. Brill, 2004.

."Newsprint Theology: Bible in the Context of HIV and AIDS.” Pages 161-86 in Out of Place: Doing Theology on the Crosscultural Brink. Edited by Jione Havea and Clive Pearson. London: Equinox Publishing, 2011.

. "The Not So Silent Citizen: Hearing Embodied Theology in the Context of HIV and AIDS in South Africa." Pages 23-42 in Heterotopic Citizen: New Research on Religious Work for the Disadvantaged. Edited by Trygve Wyller. Göttingen: Vandenhoeck \& Ruprecht, 2009. . ed. Reading Other-Wise: Socially Engaged Biblical Scholars Reading with Their Local Communities. SemeiaSt 62. Atlanta: Society of Biblical Literature and Leiden: E. J. Brill, 2007. . The Stolen Bible: From Tool of Imperialism to African Icon. Leiden: Brill / Pietermaritzburg: Cluster Publications, 2016. . "Tracing the 'Kairos' Trajectory from South Africa (1985) to Palestine (2009): Discerning Continuities and Differences.” JTSA 143 (2012): 4-22.

West, Gerald O. and Sithembiso Zwane. ““Why Are You Sitting There?” Reading Matthew 20:1-16 in the Context of Casual Workers in Pietermaritzburg, South Africa.” Pages 175-88 in Matthew: Texts@Contexts. Edited by Nicole Duran Wilkinson and James Grimshaw. Minneapolis: Fortress Press, 2013.

Whybray, R. N. Isaiah 40-66. London: Oliphants, 1975.

Gerald O. West, School of Religion, Philosophy, and Classics, \& Ujamaa Centre, University of KwaZulu-Natal, South Africa, Email: West@ukzn.ac.za. 